\title{
DINAMIKA KELEMBAGAAN PENDIDIKAN ISLAM DI INDONESIA
}

\author{
Sarwadi \\ Sekolah Tinggi Ilmu Tarbiyah Madani Yogyakarta \\ e-mail: sarwadis@gmail.com
}

\begin{abstract}
Abstrak
Pendidikan Islam telah eksis di negeri ini bahkan sebelum Indonesia lahir. Dalam perjalananya pendidikan islam terus mengalami dinamika dari masa ke masa. Perubahan pola dan bentuk secara kelembagaan ini tentunya sangat unik dan menarik bahwa pendidikan Islam tak pernah berhenti berproses untuk membangun dan mencerdaskan anak bangsa lintas generasi. Dimulai dari surau, masjid, kemudian menjadi pesantren, Madrasah, sekolah Islam dan akhirnya muncul banyak model kelembagaan yang sangat variatif. Bahkan ini banyak figur-figur nasional yang merupakan anak-anak dari lembaga pendidikan Islam.
\end{abstract}

Kata Kunci: Penddikan Islam, dinamika, kelembagaan

Islamic education has existed in this country even before Indonesia was born. In its journey Islamic education continues to experience dynamics from time to time. Changes in institutional patterns and forms are certainly very unique and interesting that Islamic education has never stopped proceeding to develop and educate children of the nation across generations. Starting from Surau, the mosque, then becoming Islamic boarding schools, Madrasas, Islamic schools and finally a variety of institutional models emerged. In fact, there are many national figures who are children of Islamic education institutions.

Keywords: Islamic education, dynamics, institutions 


\section{A. Pendahuluan}

Pendidikan adalah salah satu faktor yang sangat menentukan dan berpengaruh terhadap perubahan suatu bangsa. Melalui pendidikan diharapkan dapat menghasilkan generasi penerus yang berkarakter kuat, kokoh untuk menjalankan tongkat estafet kemepimpinan bangsa. Dalam rentetan sejarah perkembangan kelembagaan pendidikan Islam di Indonesia telah mengalami beberapa perkembangan.

Sejarah perkembangan lembaga pendidikan di Indonesia mempunyai rentetan yang sangat panjang, yaitu sepanjang sejarah bangsa ini atau malah lebih panjang dari sejarah Indonesia. Sebab sebelum Indonesia berdiri proses pendidikan telah berjalan dalam sebuah insttitusi di lingkungan masyarat yang dikenal dengan pesantren. Sebagaimana dikatakan oleh Nur Inayah dan Endry Fatimaningsih bahwa Pondok pesantren sebagai lembaga pendidikan dan pusat penyebaran agama Islam lahir dan berkembang semenjak masa-masa permulaan kedatangan agama Islam di Indonesia. ${ }^{1}$

Perkembangan lembaga pendidikan Islam di Indonesia selanjutnya dikenal dengan madrasah, yaitu merupakan fenomena modern yang muncul pada awal abad ke-20. Membicarakan madrasah di Indonesia dengan sejarah munculnya lembaga-lembaga pendidikan tradisional Islam seringkali tidak

1 Nur Inayah dan Endry Fatimaningsih, Sistem Pendidikan Formal Di Pondok Pesantren (studi pada pondok pesantren Babul Hikmah Kecamatan Kalianda Kabupaten Lampung Selatan), Jurnal Sociologie, Vol. 1, No. 3, h. 215-128 
bisa dipisahkan dari pembicaraan mengenai pesantren cikalbakalnya. Dengan kata lain, madrasah merupakan perkembangan lebih lanjut dari pesantren. Karena itu menjadi penting untuk mengamati proses historis sebagai mata rantai yang menghubungkan perkembangan pesantren di masa lalu dengan munculnya madrasah di kemudian hari. ${ }^{2}$

Menjelang abad ke 21, ada perubahan yang cukup menarik mengenai trend pendidikan Islam di Indonesia, yaitu dengan lahirnya Sekolah-sekolah Islam Terpadu. Kemunculan sekolah ini dilatarbelakangi oleh adanya ketidakpuasan sebagian besar aktor gerakan Islam di Indonesia terhadap perkembangan sistem pendidikan nasional yang dualistik. Makalah ini ingin memaparkan secara singkat perkembangan tiga institusi pendidikan Islam diindonesia yang mempunyai karakter tersendiri, yaitu pesantren, madrasah dan sekolah islam terpadu.

\section{B. Lembaga Pendidikan Di Indonesia}

\section{Pondok Pesantren}

Pondok pesamtren berarti tempat tinggal/menginap (asrama), dan pesantren berarti tempat para santri mengkaji agama Islam dan sekaligus di asramakan. Menurut M.Arifin dikutip oleh Mujamil Qomar, pondok pesantren merupakan suatu lembaga pendidikan Islam yang tumbuh serta diakui oleh masyarakat sekitar, dengan sistem asrama (komplek)

${ }^{2}$ Mahmud Arif, Pendidikan Islam Tranfirmatif, ( Yogyakarya: LKIS, 2008), 202 
dimana santri-santri menerima pendidikan agama melalui sistem pengajian yang sepenuhnya berada dibawah kedaulatan dari seorang kiai dengan ciri-ciri khas yang bersifat kharismatik serta independen dalam segala hal. Penggunaan gabungan kedua istilah antara pondok dengan pesantren menjadi pondok pesantren, sebenarnya lebih mengakomodasikan karakter keduanya. Namun penyebutan pondok pesantren kurang jami' ma'ni (singkat padat). Selagi perhatiannya dapat diwakili istilah yang lebih singkat, karena orang lebih cenderung mempergunakan yang pendek. Maka pesantren dapat digunakan untuk menggantikan pondok atau pondok pesantren.

a. Elemen-elemen Pesantren

Dhofier mengungkapkan bahwa lembaga pendidikan pesantren memiliki beberapa elemen dasar yang merupakan ciri khas dari pesantren itu sendiri, elemen itu adalah: ${ }^{3}$

1) Pondok atau asrama

2) Tempat belajar mengajar, biasanya berupa Masjid dan bisa berbentuk lain.

3) Santri

4) Pengajaran kitab-kitab agama, bentuknya adalah kitabkitab yang berbahasa arab dan klasik atau lebih dikenal dengan istilah kitab kuning.

5) Kiai dan ustadz.

3 Zamakhsyari Dhofier, Tradisi Pesantren; Studi Tentang Pandangan Hidup Kyai, (Jakarta: LP3ES, 1994), cet. Ke-VI, h. 44 
b. Tujuan Pesantren

Tujuan pesantren merupakan bagian terpadu dari faktor-faktor pendidikan. Tujuan merupakan rumusan halhal yang diharapkan dapat tercapai melalui metode, sistem dan strategi yang diharapkan. Dalam hal ini tujuan menempati posisi yang amat penting dalam proses pendidikan sehingga materi, metode dan alat pengajaran harus disesuaikan dengan tujuan yang diharapkan.

Pada dasarnya pesantren sebagai lembaga pendidikan Islam, tidak memiliki tujuan yang formal tertuang dalam teks tertulis. Namun hal itu bukan berarti pesantren tidak memiliki tujaun, setiap lembaga pendidikan yang melakukan suatu proses pendidikan, sudah pasti memiliki tujuan-tujuan yang diharapkan dapat dicapai, yang membedakan hanya apakah tujuan-tujuan tersebut tertuang secara formal dalam teks atau hanya berupa konsep-konsep yang tersimpan dalam fikiran pendidik. Hal itu tergantung dari kebijakan lembaga yang bersangkutan. ${ }^{4}$

Sebagai acuan pokok pelaksanaan pendidikan pesantren mengacu pada tujuan terbentuknya pesantren baik tujuan umum maupun tujuan khusus. Tujuan umum pesantren adalah membimbing peserta didik untuk menjadi manusia yang berkepribadian Islam yang dengan ilmu

${ }_{4}^{4}$ Departemen Agama RI, Direktorat Jenderal Kelembagaan Agama Islam, Pondok Pesantren dan Madrasah Diniyah Pertumbuhan dan Perkembangannya, (Jakarta: 2003), h. 9 
agamanya ia sanggup menjadi penyampai ajaran Islam dalam masyarakat sekitar melalui ilmu dan amalnya. Sedangkan tujuan khusus pesantren adalah mempersiapkan para santri untuk menjadi orang alim dalam agama yang diajarkan oleh kyai yang bersangkutan serta mengamalkannya dalam masyarakat. ${ }^{5}$

Menurut Mastuhu, bahwa tujuan pendidikan pesantren adalah menciptakan dan menggambarkan kepribadian muslim yaitu kepribadian yang beriman dan bertaqwa kepada tuhan, berakhlak mulia, bermanfaat bagi masyarakat atau khidmat kepada mesyarakat dengan jalan menjadi kaula atau abdi masyarakat yang diharapkan seperti kepribadian rasul yaitu pelayan masyarakat sebagaimana kepribadian Nabi Muhamad SAW, mampu berdiri sendiri, bebas dan teguh dalam kepribadian, menyebabkan agama atau menegakkan islam dan kejayaan umat ditengah-tengah masyarakat (Izz.al Islam wa al-muslimin) dan mencintai ilmu dalam rangka mengembangkan kepriadian manusia.

c. Jenis Pesantren

1) Pesantren Salaf

Pesantren bentuk salaf disebut juga dengan pesantren tradisional yang masih mempertahankan sistem pengajaran tradisional, dengan materi pengajaran kitab klasik yang disebut kitab kuning. Disamping itu model model

5 Arifin HM, Kapila Selecta Pendidikan Islam dan Umum, (Jakarta: Bumi Aksara, 1991), 
pengajarannya juga bersifat non klasik yaitu dengan menggunakan metode sorogan dan bandongan. ${ }^{6}$

Sorogan, disebut juga sebagai cara mengajar perindividu yaitu setiap santri mendapat kesempatan tersendiri untuk memperoleh pelajaran secara langsung dari kyai.sedangkan bandongan dilakukan dengan cara kyai mengajarkan kitab tertentu kepada sekelompok santri, karena itu metode ini bisa juga dikatakan sebagai proses belajar mengajar secara kolektif. Pada metode yang lebih lanjut, diteruskan dengan santri mempelajari bahan kajian sebelum mengaji kitab dengan kyai, sehingga pada saat materi itu disampaikan, santri tinggal menyimak bacaan kyai dan mencocokkan pemahamannya. ${ }^{7}$

Di samping itu pula pada awalnya sebuah pesantren memiliki falsafah kejiwaan yang disebut panca jiwa, yaitu, a) Jiwa pesantren, yang tidak didorong oleh ambisi apapun untuk memperoleh keuntungan keuntungan tertentu, tetapi semata-mata demi ibadah kepada Allah; b) Jiwa kesederhanaan tapi agung, sederhana bukan berarti pasif melarat, tetapi mengandung unsur kekuatan dan ketabahan hati, penguasaan diri dalam menghadapi segala kesulitan dan di dalamnya terkandung jiwa yang berani; c) Jiwa Ukhuwah Islamiyyah yang demokratis; d) Jiwa kemandirian,

${ }^{6}$ Fauti Subhan, Membangun Sekolah Unggulan dalam Sistem Pesantren, (Surabaya: Alpha, 2006), cet. Ke-1, h. 8

7 Hasbullah, Sejarah Pendidikan Islam Indonesia, (Jakarta: Rajawali Pers, 1999), h. 156 
bukan hanya menyangkut pribadi santri, namun pesantren harus mampu berdiri di atas kekuatannya sendiri; e) Jiwa bebas dalam memilih alternative jalan hidup dan menentukan masa depan dengan jiwa besar dan sikap optimis dalam menghadapi segala problematika dalam hidup berdasarkan nilai-nilai Islam. ${ }^{8}$

2) Pesantren khalaf

Pesantren khalaf juga disebut sebagai pesantren modern yang berusaha memadukan secara penuh sistem klasikal dan sekolah ke dalam pesantren. Pada pola ini pesantren memiliki ciri:

a) Mulai akrab dengan metodologi ilmiyah modern.

b) Semakin berorientasi pada pendidikan dan fungsional, artinya terbuka atas perkembangan dirinya.

c) Penggolongan program dan dan kegiatannya makin terbuka dan ketergantungannyapun absolut dengan kyai, yang sekaligus dapat membekali para santri dengan berbagai para santri dengan beberapa pengetahuan di luar mata pelajaran agama maupun keterampilan yang diperlukan dilapangan kerja.

d) Dapat berfungsi sebagai pusat pengembangan masyarakat. ${ }^{9}$

8 Saefuddin Zuhri, Pendidikan Pesantren di Persimpangan Jalan h. 215

924 Rush Karim, Pendidikan Islam di Indonesia dalam Transformasi Sosial Budaya, (Yogyakarta: Tiara Wacana, 1991), h. 134 
Arah dari pesantren ini adalah adanya keinginan memposisikan pesantren sebagai lembaga elit yang fleksibel. Karena pada keyakinan bahwa pesantren adalah lembaga yang mampu menciptakan sebuah sikap hidup universal yang merata, yang membentuk santri dalam hidup mandiri dengan tidak menggantungkan diri kepada siapapun dan lembaga masyarakat apapun.

\section{d. Kurikulum Pesantren}

Sistem pendidikan dipesantren tidak didasarkan pada kurikulum yang digunakan secara luas, tetapi diserahkan pada penyesuaian elastis antara kehendak kiai dengan kemampuan santrinya secara individual.Ketika masih berlangsung dilanggar (surau) atau masjid, kurikulum pengajian masih dalam bentuk yang sederhana, yakni berupa inti ajaran islam yang mendasar. Rangkaian trio komponen ajaran islam yang berupa iman, islam dan insan atau dokrin, ritual, dan mistik telah menjadi perhatian kiai perintis pesantren sebagai kurikulum yang diajarkan kepada santrinya.

Penyampaian tiga komponen ajaran islam tersebut dalam bentuk yang paling mendasar, sebab disesuaikan dengan tingkat intelektual dengan masyarakat (santri) dan kualitas keberagamaannya pada waktu itu. 


\section{Madrasah}

Institusi pendidikan ini lahir pada permulaan abad 20 yang dianggap sebagai awal periode pertumbuhan madrasah dalam sejarah pendidikan Islam di Indonesia. Memasuki abad ke-20 M, banyak dari dari kalangan Islam Indonesia yang menyadari bahwa mereka tidak akan mungkin berkompetensi dengan kekuatan-kekuatan yang menantang dari pihak kolonilisme Belanda, penetrasi Kristen, dan perjuangan untuk maju di bagian-bagian lain di Asia apabila mereka terus melanjutkan kegiatan dengan cara-cara tradisional dalam menegakkan Islam. ${ }^{10}$

Menjelang akhir abad ke-19, para anggota dari generasi baru ulama Hindia mulai menyadari bahwa metode dan tatanan berfikir (mindset) tradisional dalam Islam tidak akan sanggup menghadapi tantangan kolonialisme dan peradaban modern. Terilhami oleh bangkitnya reformisme-modernisme Islam di Timur Tenggah serta introduksi pendidikan dan asosiasi bergaya Barat di Tanah Air, mereka mulai mempromosikan modernism atas sekolah-sekolah Islam. Dengan mengkombinasikan antara pelajaran-pelajaran agama dan pelajaran umum, dan mengadopsi metode dan teknologi pendidikan dari sekolah-sekolah Barat, sekolah Islam ini

\footnotetext{
${ }^{10}$ Mahmud Arif, Pendidikan Islam Tranfirmatif, ( Yogyakarya: LKIS, 2008), 202
} 
mempresentasikan suatu bentuk baru sistem pendidikan Islam yang dinamakan dengan madrasah. ${ }^{11}$

Tumbuh dan berkembangnya madrasah di Indonesia tidak dipisahkan dengan tumbuh kembanganya ide-ide pembaruan di kalangan umat Islam. Di permulaan abad ke-20 banyak pelajar Indonesia yang belajar di Timur Tengah, sekembalinya mereka ke Indonesia mereka kembangkan ideide baru dalam bidang pendidikan salah satunya melahirkan madrasah. ${ }^{12}$

Alasan lahirnya madrasah pada era ini adalah karena respon pendidikan Islam terhadap kebijakan pendidikan Belanda, pertama kali bangsa belanda data ke Indonesia adalah untuk berdagang, oleh karena alam kekayaan Indonesia yang sangat melimpah tujuan utama untuk berdagang berubah untuk menguasai wilayah Indonesia sekaligus dengan mengembangkan pahamnya yang terkenal dengan semboyan 3 G yaitu, Glory (Kemenangan dan Kekuasaan), Gold (emas atau kekayaan bangsa Indonesia), dan Gospel (upaya salibisasi terhadap umat Islam di Indonesia).

Perkembangan sekolah yang demikian jauh dan merakyat menyebabkan tumbuhnya ide-ide di kalangan inteletual Islam, untuk memberikan respond an jawaban terhadap tantangan tersebut dengan tujuan memajukan pendidikan Islam, mereka

11 Yudi Latif, Intelegensia Muslim dan Kuasa Genealogi Intelegensia Muslim Abad ke-20, (Bandung: Mizan, 2005), Cet. 1, 108.

12 Haidar Putra Daulay, Sejarah Pertumbuhan dan Pembaruan Pendidikan Islam di Indonesia, (Jakarta: Kencana, 2014), 98. 
juga menyadari sistem pendidikan tradisional dan langgar tidak lagi sesuai lagi dengan iklim pada masa itu. Ide-ide tersebut muncul dari tokoh-tokoh yang pernah mengenyam pendidikan di Timur Tengah. Mereka mendirikan pendidikan secara perorangan maupun secara kelompok/organisasi dalam bentuk lembaga yang dinamakan madrasah atau sekolah secara teratur dan sistemis.

Perkembangan Madrasah dari Zaman ke Zaman

\section{a. Zaman Orde Lama}

Orde lama mempunyai kebijakan untuk memberikan fasilitas dan sumbangan materiil terhadap lembaga-lembaga pendidikan Islam, disambut baik oleh masyarakat walaupun tidak semuanya setuju. Kebijakan tersebut dianggap anggin segaruntuk mengembangkan pendidikan Islam di Indonesia, setelah beberapa waktu lalu sempat dikucilkan oleh pemerintah Belanda.

Kebijakan tersebut merupakan awal dari bangkitnya pendidikan Islam secara umum baik dan bersifat kelembagaan seperti madrasah, atau yang bersifat non lembaga, seperti langgar atau surau tempat mengaji, dan sempat dirasakan dampak positifnya bagi lembaga madrasah. Perkembangan madrasah pada masa Orde Lama sangat terkait dengan peran Departement Agama, lembaga inilah yang yang secara intensif memperjuangkan politik pendidikan Islam di Indonesia. Orientasi Departemen 
Agama dalam bidang pendidikan agama diajarkan di sekolahan-sekolahan. Di samping pada pada pengembangan madrasah itu sendiri. Secara sepesifik usaha ini ditangani oleh satuan khusus yang mengurusi pendidikan agama. ${ }^{13}$ Kesempatan tersebut digunakan masyarakat muslim Indonesia untuk mendirikan lembaga-lembaga pendidikan Islam. Salah satu gambaran perkembangan madrasah yang menonjol pada masa Orde Lama adalah didirikanya dan dikembangkanya Pendidikan Guru Agama (PGA) dan Pendidikan Hakim Islam Negeri.

b. Zaman Orde Baru

Pada tanggal 10-20 Agustus 1970 telah dilangsungkan pertemuan di Cibogo, Bogor, Jawa Barat dalam rangka menyusun kurikulum madrasah dalam semua tingkat secara nasional.20 Kurikulum Madrasah yang dirumuskan di Cibogo diberlakukan secara nasional berdasarkan, Keputusan Menteri Agama No. 52 Tahun 1971. Dengan beberapa perbaikan dan penyempurnaan, kurikulum itu kemudian. dikenal dengan kurikulum 1973.14

Dari struktur materi yang ditawarkan kurikulum itu sudah cukup mencerminkan perkembangan yang serius dalam rangka mengarahkan madrasah sebagai bagian dari sistem pendidikan nasional. Komponen kurikulum itu

13 Abudin Nata, Kapita Selekta Pendidikan Islam, (Jakarta, UIN Jakarta Press, 2003), 33

14 Abdul Rahman Shaleh, Madrasah dan Pendidikan Anak Bangsa Visi, Misi dan Aksi, (Jakarta: PT RajaGrafindo Persada, 2008), 34.

124 | AT-TUROTS: Jurnal Pendidikan Islam 
meliputi tidak saja mata-mata pelajaran agama tetapi juga matamata pelajaran umum dan mata-mata pelajaran kejuruan. Dengan disusunnya kurikulum madrasah secara nasional berarti kurikulum madrasah telah seragam, walaupun di sana sini tetap diperbolehkan menambah sesuai dengan ciri khas lembaga yang mendirikan. Isu sentral dari kurikulum madrasah secara nasional nampaknya masuknya mata pelajaran umum ke dalam madrasah secara dominan. Dimana mata pelajaran agama menjadi berkurang.

Dengan hanya berbekal kurikulum madrasah yang bersifat nasional saja ternyata tidak cukup untuk menjadikan madrasah sebagai bagian dari satu sistem pendidikan nasional, karena secara politis eksistensi madrasah - seperti telah disebut sebelumnya akan di bawah otoritas Depdikbud. Namun tidak disetujui oleh umat Islam, mereka lebih menghendaki madrasah tetap ada di Departemen Agama. Resistensi umat Islam itu semakin nampak ketika Presiden Soeharto mengeluarkan Keputusan Presiden No. 34 tahun 1972, kemudian diperkuat dengan Instruksi Presiden No. 15 tahun 1974, yang isinya dianggap melemahkan dan mengasingkan madrasah dari pendidikan nasional. Bahkan sebagian umat Islam memandang Kepres dan Inpres itu sebagai manuver untuk mengabaikan peran dan manfaat madrasah yang sejak zaman penjajahan telah diselenggarakan umat Islam. Situasi ini menandai hubungan 
yang cukup panas dalam hubungannya madrasah dengan pendidikan nasional.

Nampak di sini bahwa isi mata pelajaran umum kurikulum madrasah harus mengikuti kurikulum sekolah, dengan alasan agar supaya lembaga pendidikan madrasah diakui sebagai suatu sistem pendidikan nasional. Ini cukup politis, tetapi walaupun demikian, lembaga madrasah tetap mempertahankan ciri khas ke-Islamannya, terbukti dengan bergantinya kurikulum dari Depdikbud, yang selanjutnya diikuti oleh madrasah, Menteri Agama selalu mengeluarkan keputusannya (KMA) dalam rangka menyikapi pergantian kurikulum tersebut. Dan KMA itu berisi tentang desain kurikulum madrasah yang baru dengan substansi senantiasa mempertahankan ciri khas ke-Islamannya yang tergambar dalam muatan pelajaran agama. Tentu saja dengan serangkaian kebijakan itu, tidak dimaksudkan untuk mengerdilkan misi madrasah, tetapi justru sebaliknya. Madrasah semakin diperkokoh secara institusional, operasional, dan sistem pembelajarannya.

c. Madrasah Pasca Reformasi

Kehadiran UU Sisdiknas Nomor 20/2003 semakin memperkuat posisi madrasah sebagaimana telah dirintas dalam UU Sisdiknas Nomor 2/1989. Di antara indikatornya adalah penyebutan secara eksplisit madrasah yang selalu 
bersanding dengan penyebutan sekolah, yang hal ini tak ditemukan dalam undang-undang sebelumnya.

Di sisi lain munculnya UU No. 22 Tahun 1999 tentang pemerintah daerah dan UU No. 25 tahun 1999 tentang perimbangan keuangan antara pusat dan daerah. Terkait dengan madrasah, sebelumnya-sebelum munculnya UU inimadrasah secara full dan otonomi di bawah wewenang Departemen Agama, setelah munculnya UU No. 22 ini, agama tidak diotonomikan, sedangkan pendidikan termasuk bagian yang diotonomikan. Dengan demikian sebenarnya mata pelajaran umum yang ada di madrasah di bawah otoritas Dinas Pendidikan yang ada di daerah, sedangkan untuk mata pelajaran rumpun PAI tetap di bawah otoritas Departemen Agama, karena tidak diotonomikan. Konsekwensi logisnya, mata pelajaran PAI yang ada di sekolah juga menjadi otoritas Departemen Agama.

Kurikulum 2004 yang diilhami oleh UU Sisdiknas No. 20 Tahun 2003, dalam pasal 36 dan 38, disebutkan bahwa kurikulum dikembangkan dengan mengacu pada standar nasional pendidikan untuk mewujudkan tujuan pendidikan nasional, dengan prinsip diversifikasi sesuai dengan satuan pendidikan, potensi daerah dan peserta didik. Kerangka dasar dan struktur kurikulum pendidikan dasar dan menengah ditetapkan oleh pemerintah.38 Melihat realitas 
yang demikian madrasah juga harus bersikap, dengan tetap mempertahankan ciri khas ke Islamannya.

Kurikulum Madrasah Aliyah tahun 2004 disebut Kurikulum Berbasis Kompetensi (KBK). Substansi KBK adalah kompetensi, sedangkan kompetensi merupakan pengetahuan, ketrampilan, dan nilai-nilai dasar yang direfleksikan dalam kebiasaan berpikir dan bertindak yang dilakukan secara konsisten dan terus menerus, sehingga memungkinkan seseorang untuk menjadi kompeten dalam bidang tertentu.Dengan kata lain, kompeten mempunyai arti memiliki pengetahuan, ketrampilan dan nilai-nilai dasar untuk melakukan sesuatu. ${ }^{15}$ Kurikulum Berbasis Kompetensi menekankan pada hasil dan proses. Pengembangan kurikulum yang berorientasi pada hasil menekankan pada pemahaman, pengahayatan secara komprehensip dan perwujudannya dalam berfikir dan berbuat atau bertindak sebagai dampak dari pemahaman dan pengahayatan pengetahuan, ketrampilan dan nilai-nilai. Pengembangan kurikulum berorientasi pada proses menekankan pada terlaksananya proses pembelajaran dan suasana yang kondusif bagi pembentukan atau pencapaian kompetensi. ${ }^{16}$

\footnotetext{
15 Departemen Agama RI, Madrasah Aliyah Kejuruan Arah dan Prospek Pengembangan (Jakarta: Direktorat Jenderal Kelembagaan Agama Islam, 2004), 40. Lihat juga, Syafrudin Nurdin, Model Pembelajaran Yang Memperhatikan Keragaman Individu Siswa dalam Kurikulum Berbasis Kompetensi (Jakarta: Quantum Teaching, 2005), xi.

${ }^{16}$ Rachman, Madrasah dan Pendidikan Anak Bangsa, Visi, Misi dan Aksi, 186.
} 
Disamping KBK berorientasi pada hasil dan proses, KBK juga memperhatikan keberagaman yang dapat dimanifestasikan sesuai dengan kebutuhannya. ${ }^{17}$ Munculnya KBK pendidikan berbasis multikultural kiranya dapat direalisasikan. Pada kurikulum tahun 2004, jenis mata pelajaran madrasah dengan sekolah umum sama, MI sama dengan SD, MTs sama dengan SMP, MA sama dengan SMA, MAK sama dengan SMK. Bedanya hanya di Pendidikan Agama, baik jenis maupun alokasi waktunya, di sekolah umum berkisar 2-3 jam perminggu, di madrasah 7-12 jam perminggu. ${ }^{18}$ Perbedaan alokasi waktu PAI di SMA dengan di MA cukup tinggi, karena kurikulum MA mempertahankan ciri khas ke-Islamannya.

\section{Sekolah Islam Terpadu}

Sekolah Islam Terpadu merupakan pendatang baru dalam lanskap pengembangan model lembaga pendidikan di Indonesia. Meskipun baru berdiri pertama kali pada akhir abad ke-20, sekolah ini telah berkembang ke seluruh wilayah Indonesia. Dalam waktu yang relatif singkat, jumlah sekolah Islam terpadu telah mencapai 10.000 sekolah di seluruh wilayah Indonesia. ${ }^{19}$ Kemunculan sekolah ini dilatarbelakangi oleh adanya ketidakpuasan sebagian besar aktor gerakan Islam

17 Departemen Agama RI, Madrasah Aliyah Kejuruan Arah dan Prospek Pengembangan, 42

18 Rachman, Madrasah dan Pendidikan Anak Bangsa, Visi, Misi dan Aksi, 202.

19 Suyatno. 2013a. "Sekolah Islam Terpadu: Filsafat, Ideologi, dan Tren Baru Pendidikan Islam Di Indonesia", Jurnal Pendidikan Islam, Volume II, Nomor 2. 
di Indonesia terhadap perkembangan sistem pendidikan nasional. ${ }^{20}$ Adanya dikotomi ilmu antara ilmu agama dan umum di sekolah telah menyebabkan lembaga pendidikan di Indonesia tidak mampu menciptakan lulusan yang berkepribadian utuh. Dikotomi ilmu akhirnya melembaga dalam bentuk dualisme sistem pendidikan nasional (Azra, 1998). Di satu sisi, ada sekolah-sekolah agama yang berada di bawah Kementerian Agama, mulai dari RA, MI, MTs, MA, hingga Perguruan Tinggi Agama Islam (PTAI). Di sisi lain, ada sekolah-sekolah umum yang berada di bawah Kementerian Pendidikan dan Kebudayaan mulai dari TK, SD, SMP, SMA, hingga Perguruan Tinggi Umum (PTU). ${ }^{21}$

Dua model lembaga pendidikan ini diangggap oleh para pendiri Sekolah Islam Terpadu tidak mampu menjawab tantangan dan kebutuhan zaman. Lembaga pendidikan umum hanya membekali siswa tentang ilmu-ilmu umum yang jauh dari nilai-nilai tauhid. Hasilnya, meskipun para siswa memiliki kemampuan penguasaan sains dan teknologi, mereka tidak memiliki basic pendidikan moral yang kokoh sehingga dapat terjerumus ke dalam penyakit budaya modern, semisal; free seks, penggunaan narkoba, kenakalan remaja, dan lainlain. Sebaliknya, lembaga pendidikan Islam hanya membekali siswa tentang ilmu-ilmu agama ansich, sehingga mereka tidak

20 Suyatno, 2013b. “Sekolah Islam Terpadu (Genealogi, Ideologi, dan Sistem Pendidikan)". Disertasi. Program Pascasarjana UIN Sunan Kalijaga Yogyakarta.

21 Sutrisno. 2011. Pembaharuan dan Pengembangan Pendidikan Islam. Yogyakarta: Fadhilatama. 
mampu menguasai sains dan teknologi. Meskipun memiliki pondasi moral yang kuat, mereka tidak dapat eksis di tengahtengah perkembangan zaman modern. ${ }^{22}$ Menurut para aktor gerakan Sekolah Islam Terpadu, kondisi pendidikan yang dualistik tersebut sudah tidak selayaknya dipertahankan. Kedua sistem tersebut harus ditinggalkan dan ditata ulang secara tuntas. Kedua sistem harus dipadukan secara integral. Sistem yang ditimbulkannya harus diisi dengan semangat Islam dan, meminjam istilah al-Faruqy, berfungsi sebagai sebuah bagian yang integral dari program ideologisnya. ${ }^{23}$ Problem klasik tentang dikotomi maupun dualisme ilmu agama dan ilmu umum harus segera dicarikan solusinya baik pada tingkatan filosofis paradigmatik maupun sampai pada teknis departemental. Upaya pengembangan pendidikan harus menuju pada integritas antara ilmu agama dan ilmu umum sehingga tidak melahirkan jurang pemisah antara keduanya, sebab dalam pandangan Islam, ilmu pengetahuan adalah satu yaitu yang bersumber dari Allah swt. Islam tidak pernah membedakan antara ilmu-ilmu agama dan ilmu umum atau tidak berpandangan adanya dikotomi dalam ilmu pengetahuan. Ilmu pengetahuan berasal dari satu sumber yaitu Allah swt. Oleh karena itu, menurut para pendiri Sekolah Islam

\footnotetext{
22 Noorhaidi Hasan. 2011. "Islamizing Formal Education: Integrated Islamic School and New Trend in Formal Education Institution in Indonesia". Artikel. S. Rajartanam School of International Studies Singapore.

23 Islamil Raji' Al-Faruqy. 1984. Islamisasi Pengetahuan. terj. Anas Mahyudin. Bandung: PustakaPerpustakaan Salman Institute Teknologi.
} 
Terpadu, dibutuhkan sebuah lembaga pendidikan alternatif yang dapat menjembatani dualisme dalam sistem pendidikan nasional. Tidak hanya penguasaan sains dan teknologi semata, atau sebaliknya, hanya penguasaan ilmu agama ansich, siswa perlu dibekali sains dan teknologi dan ilmu agama secara utuh dengan pendekatan epistemologi yang integratif sehingga dapat menghasilkan siswa dengan kepribadian utuh pula.

a. Kurikulum Sekolah Islam Terpadu

Kurikulum bisa diartikan serangkaian pengalaman belajar. Dalam undang-undang No. 2 tahun 1989 didefinisakan sebagai seperangkat rencana dan pengaturan mengenai isi dan bahan pelajaran serta cara yang digunakan sebagai edoman penyelenggaraan kegiatan belajar mengajar. Filsafat pendidikan ikembangkan berdasarkan filsafat pendidikan dan lingkungan. Kurikulum yang digunakan di SDIT mengikuti Kurikulum Tingkat Satuan Pendidikan (KTSP). Namun dalam prakteknya, pelaksanaan kurikulum ini disesuaikan dengan kebutuhan sekolah, yaitu dengan adanya penambahan jam dan menggunakan pendekatan religius.

Pengelolaan kurikulum disesuaikan dengan kebutuhan sekolah. Misal dalam pengelolaan SDM setiap tahun dilakukan analisis apakah untuk tahun depan mencukupi atau tidak jika SDIT akan melakukan perekrutan guru bantu jika mencukupi tidak akan dilakukan perekrutan. Upaya 
yang dilakukan oleh pihak sekolah untuk meningkatkan kualitas interaksi belajar mengajar antara lain: setiap tahun diadakan raker, latihan kelompok kerja guru (KKG), Moroja'ah atau saling enyimak, workshop, seminar (pendidikan karakter) dan Study banding. Dalam elaksanaan kurikulum, terdapat kendala-kendala yang dihadapi. Diantaranya, dengan perubahan-perubahan kurikulum, sekolah kesulitan yaitu dalam prsoses penyesuaian diri, karena dibutuhkan energi yang luar biasa. Selain itu, dengan adanya perubahan kurikulum, berarti juga ada perubahan dalam penyusunan ssilabus dan RPP.

Sekolah Islam Terpadu secara total mengadopsi kurikulum dari Kementerian Pendidikan dan Kebudayaan. Semua mata pelajaran yang ada dalam kurikulum Kementerian Pendidikan dan Kebudayaan sepenuhnya "diterima" dan diajarkan dalam kurikulum Sekolah Islam Terpadu. Lima rumpun mata pelajaran yang ada dalam Undangundang Sistem Pendidikan Nasional yang terdiri dari rumpun mata pelajaran Agama dan Akhlak Mulia, Kewarganegaraan dan Kepribadian, Ilmu Pengetahuan dan Teknologi, Estetika, serta Jasmani, Olah Raga, dan Kesehatan merupakan bagian integral dari struktur kurikulum Sekolah Islam Terpadu. Bahkan diakui oleh para pendiri Sekolah Islam Terpadu, lima rumpun mata pelajaran tersebut merupakan bagian dari ajaran Islam. Kelima rumpun mata 
pelajaran tersebut tidak bertentangan dengan ajaran Islam. Selain itu, mempelajari sains dan teknologi merupakan bagian pengabdian seorang hamba kepada Allah swt. Sekolah Islam Terpadu hanya menambah beberapa mata pelajaran dalam struktur kurikulumnya, yang dinamakan dengan program ke-Islam Terpadu-an (ke-IT-an). Oleh karena itu, diintegrasikannya antara kurikulum pendidikan agama dan umum ditambah dengan program ke-IT-annya merupakan upaya untuk melakukan islamisasi kurikulum pendidikan.

Kurikulum Sekolah Islam Terpadu juga membawa dampak islamisasi kegiatan pembelajaran di kelas. Kurikulum Sekolah Islam Terpadu melakukan islamisasi proses pembelajaran dengan tujuan untuk membentuk kesadaran dan pola berpikir secara integral dalam perspektif Islam. Wujud islamisasi kegiatan pembelajaran di kelas adalah adanya pembelajaran yang terintegrasi antara berbagai mata pelajaran. Semua guru dituntut untuk menyajikan semua materi pembelajaran sebagai bagian dari proses pendidikan melalui pendekatan integral. Bahkan indikator-indikator yang digunakan untuk mengukur tercapainya sebuah kompetensi tidak hanya dilihat dari penguasaan terhadap indikator-indikator dari mata pelajaran saja, namun juga dilihat dari komitmen keislamannya. Islamisasi kurikulum dipengaruhi oleh 
pandangan bahwa Islam tidak mengenal adanya pemisahan antara ilmu umum dan ilmu agama. Tindakan membedakan serta mengkotakkotakkan pendidikan umum di satu pihak dan pendidikan agama di pihak lain merupakan penyebab utama dari kerancuan dan kesenjangan pendidikan di Indonesia dengan segala akibat yang ditimbulkannya. ${ }^{24}$

Tujuan pendidikan nasional, bagi mereka, tidak mungkin tercapai melainkan dengan kembali kepada paradigma pendidikan Islam, yakni pendidikan yang telah dicontohkan oleh Nabi Muhammad saw. dan para salaf alsālih. Pendidikan harus dijauhkan dari sistem sekuler sebagaimana yang berjalan saat ini. Pendidikan harus dikembalikan kepada ruh dan spirit ajaran Islam. ${ }^{25}$ Hal ini juga dipengaruhi oleh paradigma bahwa Islam adalah agama yang kāffah dan merupakan sistem kehidupan yang menyeluruh yang di dalamnya memuat sistem ekonomi, politik, sosial, dan pendidikan. Agama harus wujud dalam semua aspek kehidupan sehingga tidak dibenarkan adanya penyempitan terhadap makna agama bahwa agama hanya dimaknai sebagai aspek teologis normatif sebagaimana yang diajarkan oleh pesantren, madrasah, ataupun Pendidikan Agama Islam di sekolah umum.

\footnotetext{
${ }^{24}$ Suyatno, Sekolah Islam Terpadu Dalam Sistem Pendidikan Nasional, Jurnal “AlQalam" Volume 21 Nomor 1 Juni 2015

${ }^{25}$ Masruri, Eri. "Membangun Paradigma Baru Pendidikan Islam Terpadu" sebuah alternatif, Makalah, disampaikan dalam diskusi pendirian Jaringan Sekolah Islam Terpadu (JSIT) Yogyakarta.
} 
b. Kekhasan Sekolah Islam Terpadu

Sekolah Islam Terpadu sangat menekankan penilaian aspek afektif dan psikomotorik, selain penilaian kognitf melalui ulangan harian, ujian tengah semester, maupun ujian akhir sekolah. Penilaian sikap dilakukan melalui pengamatan guru setiap hari. Kedekatan hubungan antara guru dan siswa di sekolah sangat memudahkan bagi guru untuk memberikan penilaian secara autentik dan objektif. Penilaian ketrampilan diutamakan dengan praktek.

Untuk menopang penilaian siswa secara komprehensif, sekolah juga menerapkan adanya buku penghubung. Buku penghubung ini dipakai sebagai sarana komunika antara guru dengan orang tua siswa agar perkembangan siswa di sekolah juga terpantau oleh guru. ${ }^{26}$

Ada sepuluh karakter dari kepribadian Muslim menurut tujuan pendidikan Sekolah Islam Terpadu. Sepuluh karakter kepribadian Muslim ini biasa disebut dengan sepuluh muwasafat. Penjenjangan ini sama dengan konsep muwasafat yang dimiliki oleh Ikhwanul Muslimin, yakni sebagai berikut:

1) memiliki akidah yang lurus. Indikator dari karakter ini adalah; mengimani rukun Islam, mematuhi dan tunduk kepada Allah swt., mengikhlaskan amal untuk Allah swt., beriman kepada nikmat dan siksa kubur,

26 Suyatno, Sekolah Islam Terpadu Dalam Sistem Pendidikan Nasional, Jurnal “AlQalam" Volume 21 Nomor 1 Juni 2015 
mensyukuri nikmat Allah swt. Saat mendapatkannya, menjadikan setan sebagai musuh, tidak bersumpah selain atas nama Allah swt., tidak merasa sial mendengar dan melihat sesuatu, tidak menghadiri perdukunan dan paranormal, tidak meminta tolong kepada jin atau orang yang bekerja sama dengan jin, dan tidak meminta kepada orang yang meninggal.

2) beribadah yang benar. Karakter ini memiliki indikator sebagai berikut; ihsan dalam thoharoh, ihsan dalam shalat lima waktu, cinta membaca dan menghafal alQuran, berpuasa fardhu pada bulan ramadhan, ada kecintaan terhadap shalat berjamaah, mendirikan qiyam al-lail minimal sekali dalam sepekan, berpuasa sunnah minimal sekali dalam sepekan, hafal satu juz al-Quran, menutup segala kegiatan dengan istighfar, berdoa pada waktu-waktu mustajab, dan berdzikir dalam segala keadaan.

3) berakhlak mulia. Karakter ini dicirikan dengan indikator sebagai berikut; memenuhi janji, jujur, berbuat baik kepada orang lain, menjaga kehormatan keluarga, menyayangi yang lebih muda, menghormati yang lebih tua, menjaga pandangan, menjaga rahasia, menutupi aib orang lain, menggunakan barang orang lain dengan seizin pemiliknya, menyebarluaskan salam, menjauhi hal-hal dan perbuatan haram, berteman dengan orang 
baik, rendah hati dan jauh dari sifat sombong, punya prinsip dan tidak ikut-ikutan, tidak mencaci maki, tidak mengadu domba, dan tidak ghibah dan ngrumpi.

4) mandiri. Karakter ini memiliki indikator sebagai berikut; menjauhi perbuatan tercela, memenuhi hak orang lain, belajar menabung, menjaga fasilitas umum, menjaga fasilitas dan barang pribadi, dan memenuhi kebutuhan sesuai dengan kemampuan (mandi sendiri, tidur sendiri, dan aktifitas pribadi lainnya).

5) berwawasan dan berpengetahuan luas. Karakter ini memiliki indikator sebagai berikut; mempunyai kemampuan membaca dan menulis, mempunyai kemampuan mendengarkan dan mengutarakan pendapat, memperhatikan hukum-hukum tilawah, mengetahui sejarah Nabi saw., sungguh-sungguh dalam mengerjakan tugas, menghafal satu juz al-Quran dan Hadis pilihan, dan menyadari adanya gazw al-fikri (perang pemikiran) dengan orang kafir dan penentang Islam.

6) berbadan sehat dan kuat. Karakter ini memiliki indikator sebagai berikut; menjaga kebersihan dan ketertiban di rumah, sekolah maupun masyarakat, berolahraga secara teratur, bangun pagi sebelum fajar, hidup sehat, tidak mendekati orang yang merokok, menggunakan narkoba, 
makan dan minum mengikuti Rasulullah saw., dan menghindari penyakit menular.

7) bersungguh-sungguh terhadap dirinya. Karakter ini memiliki indikator sebagai berikut; menjauhi segala yang haram, menjauhi tempat-tempat yang haram, dan menjaga kemanan diri.

8) terampil mengelola segala urusannya. Karakter ini memiliki indikator sebagai berikut; terbiasa menyusun rencana kegiatan, tidak terburu-buru, dan mengisi buku harian.

9) disiplin waktu. Karakter ini memiliki indikator sebagai berikut; tepat waktu, dan menggunakan waktu untuk hal yang bermanfaat.

10) bermanfaat bagi orang lain. Karakter ini ditandai dengan indikator sebagai berikut; membantu kedua orang tua, senantiasa mendoakan kedua orang tua, membantu yang membutuhkan dengan tenaga, uang dan fikiran, mendiakan teman dan Muslim lainnya, dan menjalankan tugas di rumah, sekolah maupun di masyarakat

Dengan sistem yang dikembangkan di Sekolah Islam Terpadu, sepuluh karakter ini terinternalisasi bukan hanya pada siswa tetapi kepada semua stakeholder mulai dari pengurus dan staf yayasan, kepala sekolah, guru, murid dan orang tua murid. Para pengurus dan staf, guru, kepala sekolah serta karyawan mendapatkan internalisasi 10 
karakter melalui proses pembinaan komitmen dalam bentuk halaqah ta'lim rutin setiap pekan sekali, untuk para orang tua murid, pembinaan 10 karakter ini diberikan melalui kegiatan parenting yang dilaksanakan sekali dalam sebulan. Sedangkan para siswa diberikan dalam bentuk pembelajaran yang terintegrasi dalam semua bidang studi atau mata pelajaran. Dengan demikian, semua stakeholder mendapat layanan pendidikan/internalisasi nilai-nilai dari 10 karakter tersebut. ${ }^{27}$

\section{Penutup}

Demikianlah dinamika lembaga pendidikan Islam di Indonesia sejak awal sampai pada perkembangan terakhir ini. Bahwa pada awalnya pendidikan Islam di Indonesia benar-benar menganut sistem yang tradisional dan mengikuti sistem yang diajarkan dalam kitab-kitab klasik. Para perkembangan berikutnya lembaga pendidikan Islam berkembang sesuai dengan tuntutan zaman, yaitu berkembang dengan munculnya madrasah sejak zaman penjajahan kolonial.

Madrasah yang ada di indonesia juga berkembang dari waktu ke waktu yang disesuaikan dengan tuntunan zaman. Pada awal perndirian madrasah yang hanya berorientasi pada pelajaraan-pelajaran agama, kemudian berangsur-angsur

2727 Noorhaidi Hasan. 2011. "Islamizing Formal Education: Integrated Islamic School and New Trend in Formal Education Institution in Indonesia". Artikel. S. Rajartanam School of International Studies Singapore. 
mengadobsi sistem pendidikan nasional dengan porsi pendidikan agama 30\% dan pendidikan umum 70\%. Pendekatan sistem madrasah yang tidak jauh dengan pendidikan nasional secara umum, menbuat keprihatinan beberapa pihak sehingga muncullah sekolah islam teradu yang berangan-angan untuk menjadi solusi kelemahan-kelemahan terhadap institusi pendidikan sebelumnya. 


\section{DAFTAR PUSTAKA}

Abdul Rahman Shaleh, 2008. Madrasah dan Pendidikan Anak Bangsa Visi, Misi dan Aksi, Jakarta: PT RajaGrafindo Persada.

Abudin Nata, 203. Kapita Selekta Pendidikan Islam, Jakarta, UIN Jakarta Press.

Arifin HM, 1991. Kapila Selecta Pendidikan Islam dan Umum, Jakarta: Bumi Aksara.

Departemen Agama RI, 203. Direktorat Jenderal Kelembagaan Agama Islam, Pondok Pesantren dan Madrasah Diniyah Pertumbuhan dan Perkembangannya, Jakarta: Departemen Agama RI.

Fauti Subhan, Membangun Sekolah Unggulan dalam Sistem Pesantren, (Surabaya: Alpha, 2006), cet. Ke-1, h. 8

Haidar Putra Daulay, 2014. Sejarah Pertumbuhan dan Pembaruan Pendidikan Islam di Indonesia, Jakarta: Kencana.

Hasbullah, 1999. Sejarah Pendidikan Islam Indonesia, Jakarta: Rajawali Pers.

Islamil Raji' Al-Faruqy. 1984. Islamisasi Pengetahuan. terj. Anas Mahyudin. Bandung: PustakaPerpustakaan Salman Institute Teknologi.

Mahmud Arif, 2008. Pendidikan Islam Tranfirmatif, Yogyakarya: LKIS.

Masruri, "Membangun Paradigma Baru Pendidikan Islam Terpadu" sebuah alternatif, Makalah, disampaikan dalam diskusi pendirian Jaringan Sekolah Islam Terpadu (JSIT) Yogyakarta.

Noorhaidi Hasan. 2011. "Islamizing Formal Education: Integrated Islamic School and New Trend in Formal Education Institution in Indonesia". Artikel. S. Rajartanam School of International Studies Singapore. 
Nur Inayah dan Endry Fatimaningsih, Sistem Pendidikan Formal Di Pondok Pesantren (studi pada pondok pesantren Babul Hikmah Kecamatan Kalianda Kabupaten Lampung Selatan), Jurnal Sociologie, Vol. 1, No. 3, h. 215-128

Rush Karim, 1991. Pendidikan Islam di Indonesia dalam Transformasi Sosial Budaya, Yogyakarta: Tiara Wacana.

Suyatno. 2013a. "Sekolah Islam Terpadu: Filsafat, Ideologi, dan Tren Baru Pendidikan Islam Di Indonesia", Jurnal Pendidikan Islam, Volume II, Nomor 2.

Suyatno, 2013b. "Sekolah Islam Terpadu (Genealogi, Ideologi, dan Sistem Pendidikan)". Disertasi. Program Pascasarjana UIN Sunan Kalijaga Yogyakarta.

Suyatno, 2015. Sekolah Islam Terpadu Dalam Sistem Pendidikan Nasional, Jurnal “Al-Qalam” Volume 21 Nomor 1 Juni 2015

Sutrisno. 2011. Pembaharuan dan Pengembangan Pendidikan Islam. Yogyakarta: Fadhilatama.

Yudi Latif, 2005. Intelegensia Muslim dan Kuasa Genealogi Intelegensia Muslim Abad ke-20, Bandung: Mizan.

Zamakhsyari Dhofier, Tradisi Pesantren; Studi Tentang Pandangan Hidup Kyai, (Jakarta: LP3ES, 1994), cet. Ke-VI, h. 44 